2017-02-01

\title{
Thermal properties of cob retrofitted with external hemplime
}

\author{
Griffiths, R
}

http://hdl.handle.net/10026.1/9275

10.1680/jcoma.15.00029

Construction Materials, Proceedings of the Institution of Civil Engineers

Thomas Telford Ltd.

All content in PEARL is protected by copyright law. Author manuscripts are made available in accordance with publisher policies. Please cite only the published version using the details provided on the item record or document. In the absence of an open licence (e.g. Creative Commons), permissions for further reuse of content should be sought from the publisher or author. 


\section{Thermal properties of cob retrofitted with external hemp-lime}

Richard Griffiths BSC, PhD

Visiting Specialist, Environmental Building Group, School of Architecture, Design and Environment, Plymouth University, Devon, UK
Steve Goodhew BSc, PhD

Associate Head of School, Environmental Building Group, School of Architecture, Design and Environment, Plymouth University, Devon, UK

Insulating earth walls with an external layer of hemp-lime improves thermal performance in a sustainable way and could promote the wider use of earth in construction. Monolithic earth walls, known in Devon as cob, are widely used in many countries with temperate climates. Earth walls are a form of sustainable construction, but their thermal performance is poor when measured against current UK Building Regulations. Non-permeable, high-performance insulation materials may cause moisture-related problems in earth walling. Therefore, this paper describes the transient thermal properties of monolithic cob walls retrofitted with external hemp-lime insulation, which offers a permeable solution. The transient thermal properties of the walls are calculated using bespoke software developed for an earlier study of brick walls and the air-to-air thermal transmittance is determined for various thicknesses of hemp-lime insulation. Typical cob walls found in Devon have $U$-values $>1 \mathrm{~W} / \mathrm{m}^{2} \mathrm{~K}$, or about three times the $0.3 \mathrm{~W} / \mathrm{m}^{2} \mathrm{~K}$ UK Building Regulations target. For a $600 \mathrm{~mm}$ thick cob wall with $250 \mathrm{~mm}$ of external hemp-lime, a $U$-value of $0.3 \mathrm{~W} / \mathrm{m}^{2} \mathrm{~K}$ is achieved. Five areas of concern are discussed briefly: caution, sustainability, acceptability, uncertainty in data and the possible energy and carbon dioxide savings.

\section{Notation}

C dwelling's annual fuel bill (£)

$D \quad$ fraction of total energy used in a dwelling for space heating

$1-D$ fraction of total energy used in a dwelling for water heating, cooking, lighting and domestic electronics

F admittance surface factor

$f \quad$ admittance decrement factor

$S \quad$ fraction of total energy loss by way of wall fabric

$1-S$ fraction of total energy loss by way of floor, roof, glazing, doors and ventilation

$U \quad$ wall's air-to-air thermal transmittance $\left(\mathrm{W} / \mathrm{m}^{2} \mathrm{~K}\right)$

UR $U$-value ratio, $\left(U_{1}-U_{2}\right) / U_{1}$

$U_{1} \quad$ air-to-air thermal transmittance of the uninsulated wall $\left(\mathrm{W} / \mathrm{m}^{2} \mathrm{~K}\right)$

$U_{2} \quad$ air-to air thermal transmittance of the insulated wall $\left(\mathrm{W} / \mathrm{m}^{2} \mathrm{~K}\right)$

$Y \quad$ admittance $\left(\mathrm{W} / \mathrm{m}^{2} \mathrm{~K}\right)$

$\phi \quad$ admittance decrement lag time (h)

$\psi \quad$ surface lag time (h)

$\omega \quad$ admittance lead time (h)

\section{Introduction}

This paper describes the thermal properties of cob walls retrofitted with layers of hemp-lime insulation in order to promote the use of earth in construction and improve its thermal performance with due regard to the overarching sustainability of the finished construction. Building designers often compare the steady-state heat loss of envelope proposals using the thermal transmittance or $U$-value. However, to model the time-dependent performance of a building, the time-dependent, or transient, thermal properties of the building envelope are required.

Earth as a building material in the UK is reviewed by Hurd and Gourley (2000) and Walker et al. (2005), while Keefe (2005) discusses the construction methods, materials, repairs and conservation issues. Warren (2000) provides a map showing the main centres of earth building in the UK, with Devon and Cornwall as part of the West Country.

$\mathrm{Cob}$, an earth wall construction technique used in the southwest of the UK, is an example of sustainable construction, but its thermal performance is poor by modern standards. Therefore, this paper proposes the external insulation of cob walls with a layer of hemp-lime, with the associated sustainability of the building element assessed by analysing energy and carbon dioxide $\left(\mathrm{CO}_{2}\right)$ savings.

Hemp-lime is a mixture of hemp stalks (shiv), a lime-based binder and water (Bevan and Woolley, 2008). This can be 
fabricated into blocks, trowelled or sprayed onto a surface. Hemp-lime offers sustainable advantages: a lower embodied energy than oil-based insulation materials and a principle component (hemp plant) that removes a significant amount of carbon dioxide from the atmosphere as it grows.

Pilkington et al. (2008) determined the thermal conductivity of cob using a time-dependent needle probe technique. The conductivity values reported will be used to determine the steady-state and transient thermal properties of cob walls. This follows earlier studies of Victorian brick and earth walls (Goodhew and Griffiths, 2005; Griffiths and Goodhew, 2012). The air-to-air thermal transmittance, or $U$-value, will be determined for both uninsulated cob and walls with hemp-lime insulation using bespoke software (Griffiths and Goodhew, 2012). The addition of an air cavity, between the cob and the hemp-lime, will also be studied.

The revised UK Building Regulations (BR, 2000, 2010) state a limiting external wall thermal transmittance of $0.3 \mathrm{~W} / \mathrm{m}^{2} \mathrm{~K}$ for new and existing dwellings, which sets the target value for this study. Any remedial strategy to reduce heat loss through cob walls (without the benefit of a cavity) must recognise the importance of controlling the moisture content in the construction. The advantage of hemp-lime is that it is breathable and will therefore allow water vapour to pass through it; the wall may get wet, but later it will dry.

\section{Aims and methodology}

The following four aims were identified.

- To highlight the need for additional insulation by reviewing the thermal properties of various examples of cob walls.

- To report the steady-state and transient thermal properties of the externally insulated walls.

- To demonstrate how cob's thermal properties might be upgraded to achieve a $U$-value equal to or less than $0 \cdot 3 \mathrm{~W} / \mathrm{m}^{2} \mathrm{~K}$.

- To indicate the possible energy and carbon dioxide savings of hemp-lime insulated cob.

The methodology comprised three stages.

Establishment of the cob wall model. For this study, the cob wall was constructed on a plinth and the various dimensions of the wall were identified, such as the dimensions of the plinth, the height of clear plinth above the external ground level and the position of the internal floors and ceilings. The density, thermal conductivity and specific heat capacity of the various components are tabulated.

- Determination of the transient, or time-dependent, thermal properties of the cob-insulation model combinations using the admittance method proposed by Pipes (1957) and reproduced by CIBSE (2006). Excel spreadsheets, developed and tested for research on solid brick walls with hemp-lime (Griffiths and Goodhew, 2012), will be used.

- Discussion of related possible energy and carbon dioxide savings.

The practicalities of adding insulating hemp-lime to the exterior of earth walls are a further consideration. Potential problems of moisture in the structure need to be addressed carefully. However, external hemp-lime is a breathable material that, if used with care, could provide a sustainable solution to the relatively high heat loss from cob-walled dwellings.

\section{Proposed model of a cob wall}

Most cob buildings in the west of the UK (the UK counties of Cornwall, Devon, Somerset and Dorset) are of two storeys (Keefe, personal communication, 2011). A typical cob wall section is reproduced by Keefe and Childs (2000). The earthstraw mixture, or cob, is placed on a stone plinth $600 \mathrm{~mm}$ and $1.0 \mathrm{~m}$ high, with $450 \mathrm{~mm}$ of plinth above the ground level. For this study, the internal floor is assumed to be level with the external ground (in practice the internal floor level is usually some $250 \mathrm{~mm}$ above the external ground level). The earth is uniformly $600 \mathrm{~mm}$ thick from the plinth to the first floor level. The wall then tapers over the second floor height from 600 to $400 \mathrm{~mm}$. Two plinth models will be considered in this work: heavy weight masonry (HM), constructed of stones and earth, and a mixture of earth or clay and granite with aggregate (EM). Here, $400 \mathrm{~mm}$ was chosen since the top of the cob wall, at the eaves, is of this thickness. Ideal dry-state cob will be compared with moist cob. The insulation will be added directly to the external surface of the cob and two cases will be studied: first, with an ideal layer of hemp-lime and, second, with a practical layer where the hemp-lime has an increased density caused by self-loading and an increased thermal conductivity due to dampness. A further study will introduce a $50 \mathrm{~mm}$ air cavity constructed using plywood sheathing and a stud frame. It is assumed that the cob, and/or hemp-lime, if protected by an air cavity, will be dry and both materials will have their lower thermal conductivity.

To assess the possible advantages of retrofitting external thermal insulation, the steady-state thermal transmittance, or $U$-value, will be determined. This can then be used to find the possible energy saving and reduction in carbon dioxide emissions associated with space heating.

\section{Calculation of the thermal properties of the walls}

The steady-state thermal transmittance and transient thermal properties of the walls were determined following the 
method reviewed briefly in CIBSE (2006: p. 3-26) and in Appendix 3.A6 (p. 3-32). Excel spreadsheets were constructed to determine the thermal properties of the various walls, assuming the wall was exposed to sinusoidal temperature variations over a $24 \mathrm{~h}$ cycle. The finite homogeneous solid layers of the walls were defined in terms of thickness, thermal conductivity, density and specific heat capacity. The conductivity and specific heat capacity of hemp-lime were given by Ian Pritchett, Lime Technology (personal communication, 2011). The mean specific heat capacity was used for the transient thermal properties (a number of alternative methods use mathematical solutions of the variable temperature heat conduction equation for heat flowing through the wall; these commercial pieces of software can be costly and are not as transparent as the chosen method).

Table 1 reproduces the thermal properties of the various materials, the thermal resistances of the internal and external surfaces and that of the air cavity, all taken from CIBSE (2006: p. 3-47). The internal and external surface resistances were taken as 0.13 and $0.040 \mathrm{~m}^{2} \mathrm{~K} / \mathrm{W}$, respectively. The $50 \mathrm{~mm}$ air cavity thermal resistance was taken as $0.18 \mathrm{~m}^{2} \mathrm{~K} / \mathrm{W}$ (CIBSE, 2006: p. 3-47). Table 1 shows the cob data for two cases, namely protected, or dry, and exposed, or moist. These values were obtained from a study by Pilkington et al. (2008) that reported the thermal conductivity of the external surface of a cob wall: $180 \mathrm{~mm}$ above the plinth and $600 \mathrm{~mm}$ above ground level as $1.2 \mathrm{~W} / \mathrm{m} \mathrm{K}$ (standard deviation $0 \cdot 1$ ), and will be classified here as wet cob. On the same wall, at $2.67 \mathrm{~m}$ above the ground at the wall head, the thermal conductivity was $0.8 \mathrm{~W} / \mathrm{m} \mathrm{K}$ (standard deviation $0 \cdot 1$ ). It was assumed that the high conductivity value near the ground level was due to the higher moisture content, while at the wall head it was assumed that the cob was relatively dry. For the calculations in this study, dry thermal conductivity will be taken as $0.8 \mathrm{~W} / \mathrm{m} \mathrm{K}$ (Table 1) and moist cob will have a conductivity value of $1.0 \mathrm{~W} / \mathrm{m} \mathrm{K}$ (Table 1). This was taken as an average of the two values found by Pilkington et al. The cob, or earth, density and specific heat capacity are from CIBSE (2006). A sensitivity/uncertainty study is provided in Section 6.4. An inner layer of the cob separated by a continuous air space, or masonry protected by tile hanging or cladding, is classified as protected. Alternatively, rendered or unrendered masonry that is directly exposed to rain is classified as exposed. The insulation added externally to the cob is shown in Table 1: ideal hemp-lime which has $165 \mathrm{~kg}$ of lime binder to $110 \mathrm{~kg}$ of hemp shiv, to give a mixture density of $275 \mathrm{~kg} / \mathrm{m}^{3}$ of installed hemp-lime.

\begin{tabular}{|c|c|c|c|c|}
\hline Material & Thickness: $\mathrm{m}$ & Density: $\mathrm{kg} / \mathrm{m}^{3}$ & Conductivity: $\mathrm{W} / \mathrm{m} \mathrm{K}$ & Specific heat capacity: J/kg K \\
\hline Internal plaster (lime and sand) & 0.02 & 1600 & 0.8 & 1000 \\
\hline External render (lime and sand) & 0.025 & 1600 & $0 \cdot 8$ & 1000 \\
\hline Plaster board & 0.013 & 950 & $0 \cdot 16$ & 840 \\
\hline Plywood sheathing & 0.013 & 500 & $0 \cdot 13$ & 1600 \\
\hline Dry cob, protected with cavity & & 1720 & $0 \cdot 8^{a}$ & 870 \\
\hline Moist cob & & 1720 & $1^{\mathrm{a}}$ & 870 \\
\hline Ideal wall hemp-lime ${ }^{b}$ & & 275 & 0.06 & 1710 \\
\hline Installed wall hemp-lime ${ }^{b}$ & & 300 & $0 \cdot 1$ & 1700 \\
\hline EPS & & 15 & 0.04 & 1450 \\
\hline Heavy weight masonry $\left(\mathrm{HM}^{\mathrm{C}}\right)$ & & 1850 & $0 \cdot 85$ & 840 \\
\hline Clay soil, granite and aggregate $(E M)^{c}$ & & 2360 & $2 \cdot 2$ & 840 \\
\hline Construction resistances & & $\mathrm{m}^{2} \mathrm{KW}$ & \multirow{5}{*}{\multicolumn{2}{|c|}{$\begin{array}{l}\text { Normal exposure } \\
\text { Between high emissivity surfaces }\end{array}$}} \\
\hline Internal surface & & $0 \cdot 13$ & & \\
\hline External surface & & 0.04 & & \\
\hline Air cavity $(50 \mathrm{~mm})$ and loft space & & $0 \cdot 18$ & & \\
\hline Tile hanging (air space, battens and tile) & & $0 \cdot 12$ & & \\
\hline
\end{tabular}

apilkington et al. (2008)

${ }^{b}$ Pritchett (private communication, 2011)

'Estimated using CIBSE (2006) data

Table 1. Input data (from CIBSE, 2006) for transient thermal properties of cob walls and plinths with hemp-lime insulation 
Table 2 reproduces the thermal property data for a selection of walls taken from table 3.49 of the current Environmental Design Guide (CIBSE, 2006). In Table 2, it is shown that an internally plastered $220 \mathrm{~mm}$ solid brick wall has a $U$-value of $2.09 \mathrm{~W} / \mathrm{m}^{2} \mathrm{~K}$, with admittance about twice as large, and a decrement lag time of $7 \cdot 4 \mathrm{~h}$. This wall would lose about seven times too much heat in the steady state by modern standards, and would have shown a relatively rapid heat response to solar gain with a high decrement factor of 0.42 with a lag time of $7 \cdot 4 \mathrm{~h}$. Walls (Table 2 ) show various $U$-values and a mixed picture regarding the decrement factors and lag times. The timber-framed wall (Table 2) with $105 \mathrm{~mm}$ of brick has an acceptable $U$-value at $0.29 \mathrm{~W} / \mathrm{m}^{2} \mathrm{~K}$, but suffers from a high decrement factor and a relatively short lag time. The last example in Table 2 is a tile hung wall from CIBS (1980, table A3.16: p. A3-24). The construction consists of plaster board, with $100 \mathrm{~mm}$ expanded polystyrene (EPS) slab, $25 \mathrm{~mm}$ air gap, breather paper and finally $10 \mathrm{~mm}$ tiles on battens. This wall has a $U$-value of $0.29 \mathrm{~W} / \mathrm{m}^{2} \mathrm{~K}$, meeting the regulatory target, but has the potential for summertime overheating, with a high proportion of incident solar radiation (99\%) appearing in the interior after a relatively short time lag of $1 \cdot 0 \mathrm{~h}$.

The thermal properties shown in Table 2 (square brackets) were calculated using the input thermal data from CIBSE (2006: p. 3-47) and the Excel spreadsheets constructed for earlier studies. The good agreement between the CIBSE wall thermal properties and the values obtained using the Excel spreadsheets allows confident application of the spreadsheets.

The following results will illustrate how the thermal performance of cob walls of various thicknesses can be improved by adding different thicknesses of insulating hemp-lime externally. It is not possible to illustrate all the combinations of earth, internal and external surface finishes together with various hemp-lime layers of differing thickness for walls with and without air cavities and tile hanging. A limited number of wall samples will be described to illustrate the thermal issues. The results will be presented following the CIBSE style; the time-dependent thermal properties will be given in a tabulated form.

\section{Results}

Results calculated for cob walls without added insulation will be presented first. Walls that meet the UK Building Regulations will be identified and some walls exposed to winddriven rain will be discussed. This section will briefly discuss application of the insulation.

Table 3 shows a selection of cob walls, which are assumed to be moist (unprotected from the external environment by an 


\begin{tabular}{lccccccccc}
$\begin{array}{l}\text { Cob } \\
\text { thickness: } \\
\mathrm{mm}\end{array}$ & $\begin{array}{c}\text { Total } \\
\text { thickness: } \\
\mathrm{mm}\end{array}$ & $\begin{array}{c}\text { Mass per } \\
\text { unit area: } \\
\mathrm{kg} / \mathrm{m}^{2}\end{array}$ & $\begin{array}{c}U \text {-value } \\
\mathrm{W} / \mathrm{m}^{2} \mathrm{~K}\end{array}$ & $\begin{array}{c}\text { Admittance } \\
\mathrm{Y}: \mathrm{W} / \mathrm{m}^{2} \mathrm{~K}\end{array}$ & $\begin{array}{c}\text { Admittance } \\
\text { lead time } \\
\omega: \mathrm{h}\end{array}$ & $\begin{array}{c}\text { Decrement } \\
\text { factor } \\
f\end{array}$ & $\begin{array}{c}\text { Decrement } \\
\text { lag time } \\
\phi: \mathrm{h}\end{array}$ & $\begin{array}{c}\text { Surface } \\
\text { factor } \\
\mathrm{F}\end{array}$ & $\begin{array}{c}\text { Surface } \\
\text { time lag } \\
\psi: \mathrm{h}\end{array}$ \\
\hline 300 & 345 & 588 & 1.9 & 4.73 & 1.25 & 0.28 & 9.49 & 0.46 & 1.69 \\
400 & 445 & 760 & 1.6 & 4.71 & 1.25 & 0.16 & $12 \cdot 31$ & 0.46 & 1.68 \\
500 & 545 & 932 & 1.38 & 4.71 & 1.25 & 0.09 & $15 \cdot 12$ & 0.46 & 1.68 \\
600 & 645 & 1104 & 1.21 & 4.71 & 1.25 & 0.05 & 17.94 & 0.46 & 1.68 \\
700 & 745 & 1276 & 1.08 & 4.71 & 1.25 & 0.03 & $20 \cdot 76$ & 0.46 & 1.68 \\
800 & 845 & 1448 & 0.97 & 4.71 & 1.25 & 0.01 & 23.58 & 0.46 & 1.68 \\
900 & 945 & 1620 & 0.89 & 4.71 & 1.25 & 0.01 & $26.39[2.39]$ & 0.46 & 1.68
\end{tabular}

Table 3. Transient thermal properties of various moist cob walls, all with $20 \mathrm{~mm}$ internal lime-sand plaster and $25 \mathrm{~mm}$ external lime-sand render

air gap). All have an internal $20 \mathrm{~mm}$ dense lime and sand plaster layer, and $25 \mathrm{~mm}$ external layer of lime and sand render. These lime and sand layers are assumed to be the typical finishes that might be found today, and the cob is assumed to range from 300 to $900 \mathrm{~mm}$. The most thermally unacceptable wall shown in Table 3 is the $345 \mathrm{~mm}$ thick wall with a $U$-value of $1.90 \mathrm{~W} / \mathrm{m}^{2} \mathrm{~K}$. The decrement factor and lag time show $28 \%$ of the incident solar radiation arriving at the interior after $9 \cdot 5 \mathrm{~h}$. This construction would not provide the adequate environmental filtering needed in a dwelling in temperate climates, with or without climate change. The thickest wall in this group (Table 3), at $945 \mathrm{~mm}$, still only has a $U$-value of $0.89 \mathrm{~W} / \mathrm{m}^{2} \mathrm{~K}$, but at least this wall has a very low decrement factor at 0.01 and a long lag time of $26.4 \mathrm{~h}$. The selection of cob walls shown in Table 3 , with the internal and external lime and sand layers demonstrates their poor thermal performance and they are all far from the modern requirement of $0.3 \mathrm{~W} / \mathrm{m}^{2} \mathrm{~K}$. In the Excel spreadsheet admittance calculations, the lag time is determined and expressed as part of the daily $24 \mathrm{~h}$ cycle. The decrement lag time for this $900 \mathrm{~mm}$ wall (Table 3) is $2.39 \mathrm{~h}$, as indicated in the square brackets. For comparison with the other times in Table 3, $24 \mathrm{~h}$ has been added to this time $(2 \cdot 39 \mathrm{~h})$ and is shown as $26.39 \mathrm{~h}$. This convention has been applied throughout this work. The surface factor and surface lag time remain constant with increasing cob thickness at 0.46 and $1.68 \mathrm{~h}$, respectively. This is the expected behaviour (see CIBSE (2006: paragraph 3.7.1.3: p. 3-33)).

Table 4 shows a selection of $400 \mathrm{~mm}$ thick exposed cob walls, all with an internal $20 \mathrm{~mm}$ dense lime and sand plaster layer and $25 \mathrm{~mm}$ of lime-sand external render. This wall thickness might be found at the eaves of a two-storey cob dwelling. The walls have an increasing thickness of ideal wall hemp-lime (Table 1) sprayed directly onto the cob in thicknesses of $50 \mathrm{~mm}$ (Table 4) through to $300 \mathrm{~mm}$ before the addition of the external finish of $25 \mathrm{~mm}$ lime-sand render. Here, it is assumed that the original cob is sound, or if there was an external layer of cement render that this would be in need of maintenance and therefore removed before the addition of the hemp-lime insulation. For these $400 \mathrm{~mm}$ cob walls to meet current regulations and to have $U$-values of $<0.3 \mathrm{~W} / \mathrm{m}^{2} \mathrm{~K}$, $150 \mathrm{~mm}$ of ideal wall hemp-lime is inadequate, while $200 \mathrm{~mm}$ of ideal wall hemp-lime would provide a margin for error, see Table 4 . The surface factor $F$ and surface lag time $\psi$ were omitted as they remain constant with increasing hemp-lime insulation thickness at 0.47 and $1.68 \mathrm{~h}$, respectively.

Table 5 presents the thermal properties of $500 \mathrm{~mm}$ exposed cob walls with installed hemp-lime insulation. A value of $500 \mathrm{~mm}$ represents the mean wall thickness found in the West Country cob-walled buildings, and the installed hemp-lime properties are the more likely to be encountered in practice. The surface factor $F$ and surface lag time $\psi$ have again been omitted as they remain constant with increasing hemp-lime insulation thickness at 0.46 and $1.68 \mathrm{~h}$, respectively. Table 5 shows that the wall with $300 \mathrm{~mm}$ of installed hemp-lime insulation meets the $U$-value target of $0.3 \mathrm{~W} / \mathrm{m}^{2} \mathrm{~K}$ (Table 5). However, this is an extremely large thickness of material to be added to the external surface of the cob wall, raising issues of aesthetics, construction and cost.

Table 6 presents the thermal properties of $600 \mathrm{~mm}$ exposed cob walls with installed hemp-lime insulation. A value of $600 \mathrm{~mm}$ represents the thickness of ground floor walls found in West Country cob-walled buildings, and the $600 \mathrm{~mm}$ is the model plinth thickness suggested in this work. The surface factor $F$ and surface lag time $\psi$ have again been omitted as they remain constant with increasing hemp-lime insulation thickness at 0.46 and $1.68 \mathrm{~h}$, respectively. Table 6 shows an improvement in results over Table 5 in that the wall with $150 \mathrm{~mm}$ of installed hemp-lime insulation (Table 6) meets the 
Wall section, inside to out

Thickness: Mass $/ \mathrm{m}^{2}$ : U-value: Admittance: Time Decrement Decrement

$\mathrm{mm} \quad \mathrm{kg} / \mathrm{m}^{2} \quad \mathrm{~W} / \mathrm{m}^{2} \mathrm{~K} \quad \mathrm{~W} / \mathrm{m}^{2} \mathrm{~K} \quad$ lead: $\mathrm{h}$ factor time lag: $\mathrm{h}$

$20 \mathrm{~mm}$ lime-sand plaster, $400 \mathrm{~mm}$ cob, $25 \mathrm{~mm}$ lime-sand render

$20 \mathrm{~mm}$ lime-sand plaster, $400 \mathrm{~mm}$ cob, $50 \mathrm{~mm}$ ideal hemp-lime, $25 \mathrm{~mm}$ lime-sand render $20 \mathrm{~mm}$ lime-sand plaster, $400 \mathrm{~mm}$ cob, $100 \mathrm{~mm}$ ideal hemp-lime, $25 \mathrm{~mm}$ lime-sand render

$\begin{array}{lllllll}445 & 760 & 1.6 & 4.72 & 1.25 & 0.16 & 12 \cdot 31 \\ 495 & 774 & 0.69 & 4.71 & 1.25 & 0.06 & 15 \cdot 12 \\ 545 & 788 & 0.44 & 4.71 & 1.25 & 0.04 & 17 \cdot 88 \\ 595 & 801 & 0.32 & 4.71 & 1.25 & 0.02 & 21 \cdot 12 \\ 645 & 815 & 0.25 & 4.71 & 1.25 & 0.013 & 24.36 \\ 695 & 829 & 0.21 & 4.71 & 1.25 & 0.007 & 27.59 \\ 745 & 843 & 0.18 & 4.71 & 1.25 & 0.003 & 30.81\end{array}$

$20 \mathrm{~mm}$ lime-sand plaster, $400 \mathrm{~mm}$ cob, $150 \mathrm{~mm}$ ideal hemp-lime, $25 \mathrm{~mm}$ lime-sand render $20 \mathrm{~mm}$ lime-sand plaster, $400 \mathrm{~mm}$ cob, $200 \mathrm{~mm}$ ideal hemp-lime, $25 \mathrm{~mm}$ lime-sand render $20 \mathrm{~mm}$ lime-sand plaster, $400 \mathrm{~mm}$ cob, $250 \mathrm{~mm}$ ideal hemp-lime, $25 \mathrm{~mm}$ lime-sand render $20 \mathrm{~mm}$ lime-sand plaster, $400 \mathrm{~mm}$ cob, $300 \mathrm{~mm}$ ideal hemp-lime, $25 \mathrm{~mm}$ lime-sand render

The surface factor and surface lag time are constant with increasing hemp-lime at 0.47 and $1.68 \mathrm{~h}$, respectively

Table 4. Transient thermal properties of $400 \mathrm{~mm}$ exposed or

moist cob walls with ideal wall hemp-lime insulation

\begin{tabular}{|c|c|c|c|c|c|c|c|}
\hline Wall section, inside to out & $\begin{array}{l}\text { Thickness: } \\
\mathrm{mm}\end{array}$ & $\begin{array}{l}\text { Mass } / \mathrm{m}^{2} \text { : } \\
\mathrm{kg} / \mathrm{m}^{2}\end{array}$ & $\begin{array}{l}\text { U-value: } \\
\mathrm{W} / \mathrm{m}^{2} \mathrm{~K}\end{array}$ & $\begin{array}{l}\text { Admittance: } \\
\mathrm{W} / \mathrm{m}^{2} \mathrm{~K}\end{array}$ & $\begin{array}{l}\text { Time } \\
\text { lead: } \mathrm{h}\end{array}$ & $\begin{array}{l}\text { Decrement } \\
\text { factor }\end{array}$ & $\begin{array}{l}\text { Decrement } \\
\text { time lag: } \mathrm{h}\end{array}$ \\
\hline 20 mm lime-sand plaster, 500 mm cob, 25 mm lime-sand render & 545 & 932 & $1 \cdot 38$ & $4 \cdot 71$ & $1 \cdot 25$ & 0.09 & $15 \cdot 12$ \\
\hline $20 \mathrm{~mm}$ lime-sand plaster, $500 \mathrm{~mm}$ cob, $50 \mathrm{~mm}$ installed hemp-lime, $25 \mathrm{~mm}$ lime-sand render & 595 & 947 & 0.82 & $4 \cdot 72$ & $1 \cdot 25$ & 0.035 & $17 \cdot 5$ \\
\hline $20 \mathrm{~mm}$ lime-sand plaster, $500 \mathrm{~mm}$ cob, $100 \mathrm{~mm}$ installed hemp-lime, $25 \mathrm{~mm}$ lime-sand render & 645 & 962 & 0.58 & 4.72 & 1.25 & 0.024 & $19 \cdot 59$ \\
\hline $20 \mathrm{~mm}$ lime-sand plaster, $500 \mathrm{~mm}$ cob, $150 \mathrm{~mm}$ installed hemp-lime, $25 \mathrm{~mm}$ lime-sand render & 695 & 977 & 0.45 & $4 \cdot 72$ & $1 \cdot 25$ & $0 \cdot 016$ & $22 \cdot 12$ \\
\hline $20 \mathrm{~mm}$ lime-sand plaster, $500 \mathrm{~mm}$ cob, $200 \mathrm{~mm}$ installed hemp-lime, $25 \mathrm{~mm}$ lime-sand render & 745 & 992 & 0.37 & 4.72 & $1 \cdot 25$ & 0.01 & $24 \cdot 75$ \\
\hline $20 \mathrm{~mm}$ lime-sand plaster, $500 \mathrm{~mm}$ cob, $250 \mathrm{~mm}$ installed hemp-lime, $25 \mathrm{~mm}$ lime-sand render & 795 & 1007 & 0.31 & $4 \cdot 72$ & $1 \cdot 25$ & 0.006 & $27 \cdot 36$ \\
\hline $20 \mathrm{~mm}$ lime-sand plaster, $500 \mathrm{~mm}$ cob, $300 \mathrm{~mm}$ installed hemp-lime, $25 \mathrm{~mm}$ lime-sand render & 845 & 1022 & 0.27 & $4 \cdot 72$ & $1 \cdot 25$ & $0 \cdot 004$ & $29 \cdot 96$ \\
\hline
\end{tabular}

The surface factor and surface lag time are constant at 0.46 and $1.68 \mathrm{~h}$, respectively

Table 5. Transient thermal properties of $500 \mathrm{~mm}$ moist cob walls

with installed hemp-lime insulation 
$U$-value target of $0 \cdot 3 \mathrm{~W} / \mathrm{m}^{2} \mathrm{~K}$, while a wall with $200 \mathrm{~mm}$ of hemp-lime insulation has a $U$-value of $0.24 \mathrm{~W} / \mathrm{m}^{2} \mathrm{~K}$, well within the target figure.

Table 7 presents the thermal properties of $800 \mathrm{~mm}$ exposed cob walls with ideal hemp-lime insulation. The value $800 \mathrm{~mm}$ represents the typical thickness of cob walls found in West Country dwellings from medieval times to the sixteenth century. The surface factor $F$ and the surface lag time $\psi$ remain constant with increasing hemp-lime insulation thickness at 0.46 and $1.68 \mathrm{~h}$, respectively. Table 7 shows that the wall with $150 \mathrm{~mm}$ of ideal hemp-lime insulation (Table 7) easily meets the $U$-value target of $0 \cdot 3 \mathrm{~W} / \mathrm{m}^{2} \mathrm{~K}$.

Table 8 shows the thermal properties of a $500 \mathrm{~mm}$ cob wall with a $50 \mathrm{~mm}$ air cavity before the hemp-lime insulation layer. A stud frame is added to the wall exterior to support $13 \mathrm{~mm}$ plywood sheathing onto which the hemp-lime is sprayed. Since the cob is now protected by an air cavity, the calculations are completed with the cob's thermal conductivity taken as dry cob (Table 1). Table 8 shows that for this wall $250 \mathrm{~mm}$ of ideal hemp-lime is required to achieve the target $U$-value. The surface factor $F$ and the surface lag time $\psi$ remain constant with increasing hemp-lime insulation thickness at 0.46 and $1.68 \mathrm{~h}$, respectively. The studs to support the plywood sheathing thermally bridge the air gap, conducting heat from the cob to the plywood. This thermal bridging effect has been ignored in these preliminary studies.

Table 9 presents the thermal properties of plinths of $600 \mathrm{~mm}$ thickness that might be found at the base of cob walls. The thermal properties of these plinths were determined with ideal-wall hemp-lime properties (Table 1) and the installed hemp-lime (Table 1). Two types of plinth are used: HM, the thermal properties of which are given in Table 1, and a mixture of clay soil, granite stones with aggregate (EM), the properties are again shown in Table 1. Table 9 shows the uninsulated plinths, the EM plinth and the HM plinth. Table 9 shows that the insulated (EM) plinth achieves the target $U$-value with $250 \mathrm{~mm}$ of ideal hemp-lime, but fails with installed hemp-lime. With the HM plinth (Table 9), $150 \mathrm{~mm}$ of ideal hemp-lime meets the target $U$-value, but $250 \mathrm{~mm}$ of installed hemp-lime is required. For EM plinths, the surface factor $F$ and surface lag time $\psi$ remain constant with increasing hemp-lime insulation thickness at 0.37 and $1.6 \mathrm{~h}$, respectively. For HM plinths, the surface factor $F$ and surface lag time $\psi$ remain constant with increasing hemp-lime insulation thickness at 0.48 and $1.68 \mathrm{~h}$, respectively.

Table 10 presents the thermal properties of $500 \mathrm{~mm}$ exposed cob walls with $20 \mathrm{~mm}$ internal lime and sand plaster, installed hemp-lime insulation and tile hanging. As there is no air cavity in this construction, both the cob and the hemp-lime 
Wall section, inside to out

$20 \mathrm{~mm}$ lime-sand plaster, $800 \mathrm{~mm}$ cob, $25 \mathrm{~mm}$ lime-sand render

$20 \mathrm{~mm}$ lime-sand plaster, $800 \mathrm{~mm}$ cob, $50 \mathrm{~mm}$ ideal hemp-lime, $25 \mathrm{~mm}$ lime-sand render

$20 \mathrm{~mm}$ lime-sand plaster, $800 \mathrm{~mm}$ cob, $100 \mathrm{~mm}$ ideal hemp-lime, $25 \mathrm{~mm}$ lime-sand render

$20 \mathrm{~mm}$ lime-sand plaster, $800 \mathrm{~mm}$ cob, $150 \mathrm{~mm}$ ideal hemp-lime, $25 \mathrm{~mm}$ lime-sand render

$20 \mathrm{~mm}$ lime-sand plaster, $800 \mathrm{~mm}$ cob, $200 \mathrm{~mm}$ ideal hemp-lime, $25 \mathrm{~mm}$ lime-sand render

$20 \mathrm{~mm}$ lime-sand plaster, $800 \mathrm{~mm}$ cob, $250 \mathrm{~mm}$ ideal hemp-lime, $25 \mathrm{~mm}$ lime-sand render

$20 \mathrm{~mm}$ lime-sand plaster, $800 \mathrm{~mm}$ cob, $300 \mathrm{~mm}$ ideal hemp-lime, $25 \mathrm{~mm}$ lime-sand render

Thickness: Mass $/ \mathrm{m}^{2}$ : U-value: Admittance: Time Decrement Decrement

$\mathrm{mm} \quad \mathrm{kg} / \mathrm{m}^{2} \quad \mathrm{~W} / \mathrm{m}^{2} \mathrm{~K} \quad \mathrm{~W} / \mathrm{m}^{2} \mathrm{~K}$ lead: $\mathrm{h}$ factor time lag: $\mathrm{h}$

$\begin{array}{rllllll}845 & 1448 & 0.97 & 4.71 & 1.25 & 0.014 & 23.58 \\ 895 & 1462 & 0.54 & 4.71 & 1.25 & 0.004 & 26.39 \\ 945 & 1476 & 0.37 & 4.71 & 1.25 & 0.002 & 29.16 \\ 995 & 1489 & 0.28 & 4.71 & 1.25 & 0.001 & 32 \cdot 4 \\ 1045 & 1503 & 0.23 & 4.71 & 1.25 & 0.001 & 36.64 \\ 1095 & 1517 & 0.19 & 4.71 & 1.25 & 0 & 38.86 \\ 1145 & 1531 & 0.17 & 4.71 & 1.25 & 0 & 42.08\end{array}$

The surface factor and surface lag time are constant at 0.46 and $1.68 \mathrm{~h}$, respectively

Table 7. Transient thermal properties of $800 \mathrm{~mm}$ moist cob walls

with ideal hemp-lime insulation

Wall section, inside to out

Thickness: Mass $/ \mathrm{m}^{2}$ : U-value: Admittance: Time Decrement Decrement

$20 \mathrm{~mm}$ lime-sand plaster, $500 \mathrm{~mm}$ cob, $50 \mathrm{~mm}$ air cavity, $13 \mathrm{~mm}$ plywood, $50 \mathrm{~mm}$ installed hemp-lime, $25 \mathrm{~mm}$ lime-sand render

$20 \mathrm{~mm}$ lime-sand plaster, $500 \mathrm{~mm}$ cob, $50 \mathrm{~mm}$ air cavity, $13 \mathrm{~mm}$ plywood, $100 \mathrm{~mm}$ installed hemp-lime, $25 \mathrm{~mm}$ lime-sand render

$20 \mathrm{~mm}$ lime-sand plaster, $500 \mathrm{~mm}$ cob, $50 \mathrm{~mm}$ air cavity, $13 \mathrm{~mm}$ plywood, $150 \mathrm{~mm}$ installed hemp-lime, $25 \mathrm{~mm}$ lime-sand render

$20 \mathrm{~mm}$ lime-sand plaster, $500 \mathrm{~mm}$ cob, $50 \mathrm{~mm}$ air cavity, $13 \mathrm{~mm}$ plywood, $200 \mathrm{~mm}$ installed hemp-lime, $25 \mathrm{~mm}$ lime-sand render

$20 \mathrm{~mm}$ lime-sand plaster, $500 \mathrm{~mm}$ cob, $50 \mathrm{~mm}$ air cavity, $13 \mathrm{~mm}$ plywood, $250 \mathrm{~mm}$ installed hemp-lime, $25 \mathrm{~mm}$ lime-sand render

$20 \mathrm{~mm}$ lime-sand plaster, $500 \mathrm{~mm}$ cob, $50 \mathrm{~mm}$ air cavity, $13 \mathrm{~mm}$ plywood, $300 \mathrm{~mm}$ installed

hemp-lime, 25 mm lime-sand render

$\mathrm{mm}$

$\begin{array}{lllllll}658 & 954 & 0.61 & 4.59 & 1.35 & 0.02 & 20.29\end{array}$

$\begin{array}{lllllll}708 & 969 & 0.47 & 4.59 & 1.35 & 0.014 & 22.69\end{array}$

$\begin{array}{lllllll}758 & 984 & 0.38 & 4.59 & 1.35 & 0.009 & 25.3\end{array}$

$\begin{array}{lllllll}808 & 999 & 0.32 & 4.59 & 1.35 & 0.005 & 27.91\end{array}$

$\begin{array}{lllllll}858 & 1014 & 0.28 & 4.59 & 1.35 & 0.003 & 30.51\end{array}$

The surface factor and surface lag time are constant at 0.49 and $1.68 \mathrm{~h}$, respectively

Table 8. Transient thermal properties of $500 \mathrm{~mm}$ dry cob walls

with air cavity and installed hemp-lime insulation 


\begin{tabular}{|c|c|c|c|c|c|c|c|}
\hline Plinth section, inside to out & $\begin{array}{c}\text { Thickness: } \\
\text { mm }\end{array}$ & $\begin{array}{c}\text { Mass } / \mathrm{m}^{2}: \\
\mathrm{kg} / \mathrm{m}^{2}\end{array}$ & $\begin{array}{l}\text { U-value: } \\
\mathrm{W} / \mathrm{m}^{2} \mathrm{~K}\end{array}$ & $\begin{array}{l}\text { Admittance: } \\
\mathrm{W} / \mathrm{m}^{2} \mathrm{~K}\end{array}$ & $\begin{array}{l}\text { Time } \\
\text { lead: } h\end{array}$ & $\begin{array}{l}\text { Decrement } \\
\text { factor }\end{array}$ & $\begin{array}{l}\text { Decrement } \\
\text { time lag: } \mathrm{h}\end{array}$ \\
\hline $20 \mathrm{~mm}$ lime-sand plaster, $600 \mathrm{~mm}$ mixed plinth (EM), $25 \mathrm{~mm}$ lime-sand render & 645 & 1488 & 2 & $5 \cdot 26$ & $0 \cdot 84$ & 0.071 & $14 \cdot 72$ \\
\hline $\begin{array}{l}20 \mathrm{~mm} \text { lime-sand plaster, } 600 \mathrm{~mm} \text { mixed plinth (EM), } 150 \mathrm{~mm} \text { ideal hemp-lime, } \\
25 \mathrm{~mm} \text { lime-sand render }\end{array}$ & 795 & 1529 & 0.33 & $5 \cdot 26$ & 0.84 & 0.01 & $23 \cdot 2$ \\
\hline $\begin{array}{l}20 \mathrm{~mm} \text { lime-sand plaster, } 600 \mathrm{~mm} \text { mixed plinth (EM), } 250 \mathrm{~mm} \text { ideal hemp-lime, } \\
25 \mathrm{~mm} \text { lime-sand render }\end{array}$ & 895 & 1557 & $0 \cdot 21$ & $5 \cdot 26$ & 0.84 & 0.003 & $29 \cdot 66$ \\
\hline $\begin{array}{l}20 \mathrm{~mm} \text { lime-sand plaster, } 600 \mathrm{~mm} \text { mixed plinth (EM), } 150 \mathrm{~mm} \text { installed hemp-lime, } \\
25 \mathrm{~mm} \text { lime-sand render }\end{array}$ & 795 & 1533 & 0.5 & $5 \cdot 26$ & 0.84 & 0.01 & $21 \cdot 37$ \\
\hline $\begin{array}{l}20 \mathrm{~mm} \text { lime-sand plaster, } 600 \mathrm{~mm} \text { mixed plinth (EM), } 250 \mathrm{~mm} \text { installed hemp-lime, } \\
25 \mathrm{~mm} \text { lime-sand render }\end{array}$ & 895 & 1563 & 0.33 & $5 \cdot 26$ & 0.84 & 0.005 & $26 \cdot 61$ \\
\hline $\begin{array}{l}20 \mathrm{~mm} \text { lime-sand plaster, } 600 \mathrm{~mm} \text { heavy weight plinth (HM), } 25 \text { mm lime-sand } \\
\text { render }\end{array}$ & 645 & 1182 & 1.07 & 4.65 & $1 \cdot 31$ & 0.034 & $19 \cdot 65$ \\
\hline $\begin{array}{l}20 \mathrm{~mm} \text { lime-sand plaster, } 600 \mathrm{~mm} \text { heavy weight plinth (HM), } 150 \mathrm{~mm} \text { ideal } \\
\text { hemp-lime, } 25 \mathrm{~mm} \text { lime-sand render }\end{array}$ & 795 & 1223 & 0.29 & 4.65 & $1 \cdot 31$ & 0.004 & 28.51 \\
\hline $\begin{array}{l}20 \mathrm{~mm} \text { lime-sand plaster, } 600 \mathrm{~mm} \text { heavy weight plinth (HM), } 250 \mathrm{~mm} \text { ideal } \\
\text { hemp-lime, } 25 \mathrm{~mm} \text { lime-sand render }\end{array}$ & 895 & 1251 & 0.2 & $4 \cdot 65$ & $1 \cdot 31$ & 0.001 & 34.98 \\
\hline $\begin{array}{l}20 \mathrm{~mm} \text { lime-sand plaster, } 600 \mathrm{~mm} \text { heavy weight plinth (HM), } 150 \mathrm{~mm} \text { installed } \\
\text { hemp-lime, } 25 \mathrm{~mm} \text { lime-sand render }\end{array}$ & 795 & 1227 & 0.41 & 4.65 & $1 \cdot 31$ & 0.005 & $26 \cdot 69$ \\
\hline $\begin{array}{l}20 \mathrm{~mm} \text { lime-sand plaster, } 600 \mathrm{~mm} \text { heavy weight plinth (HM), } 250 \mathrm{~mm} \text { installed } \\
\text { hemp-lime, } 25 \mathrm{~mm} \text { lime-sand render }\end{array}$ & 895 & 1257 & 0.29 & 4.65 & $1 \cdot 31$ & 0.002 & 31.93 \\
\hline
\end{tabular}

For the first five plinths in Table 9, the surface factor $F$ is 0.37 and surface lag time $\psi$ is $1.6 \mathrm{~h}$; for the last five plinths, $F$ is 0.48 and $\psi$ is $1.68 \mathrm{~h}$

Table 9. Transient thermal properties of clay mixture (EM) and

heavy weight mixture (HM) $600 \mathrm{~mm}$ plinths, $20 \mathrm{~mm}$ internal lime-

sand plaster with ideal and installed hemp-lime insulation 


\begin{tabular}{lccccccc}
$\begin{array}{l}\text { Hemp-lime } \\
\text { thickness: } \\
\mathrm{mm}\end{array}$ & $\begin{array}{c}\text { Total } \\
\text { thickness: } \\
\mathrm{mm}\end{array}$ & $\begin{array}{c}\text { Mass per } \\
\text { unit area: } \\
\mathrm{kg} / \mathrm{m}^{2}\end{array}$ & $\begin{array}{c}U \text {-value } \\
U: \mathrm{W} / \mathrm{m}^{2} \mathrm{~K}\end{array}$ & $\begin{array}{c}\text { Admittance } \\
\mathrm{Y}: \mathrm{W} / \mathrm{m}^{2} \mathrm{~K}\end{array}$ & $\begin{array}{c}\text { Admittance } \\
\text { lead time } \\
\omega: \mathrm{h}\end{array}$ & $\begin{array}{c}\text { Decrement } \\
\text { factor } \\
f\end{array}$ & $\begin{array}{c}\text { Decrement } \\
\text { lag time } \\
\phi: h\end{array}$ \\
\hline 50 & 620 & 907 & 0.76 & 4.71 & 1.25 & 0.03 & $17 \cdot 15$ \\
100 & 670 & 922 & 0.55 & 4.71 & 1.25 & 0.02 & $19 \cdot 33$ \\
150 & 720 & 937 & 0.43 & 4.71 & 1.25 & 0.02 & 21.9 \\
200 & 770 & 952 & 0.36 & 4.71 & 1.25 & 0.01 & 24.53 \\
250 & 820 & 967 & 0.3 & 4.71 & 1.25 & 0.006 & $27 \cdot 14$
\end{tabular}

No air cavity. The surface factor $F$ is 0.46 and surface lag time $\psi$ is $1.68 \mathrm{~h}$

Table 10. Transient thermal properties of $500 \mathrm{~mm}$ exposed or moist cob walls with $20 \mathrm{~mm}$ internal lime-sand plaster, installed hemp-lime insulation and tile hanging

\begin{tabular}{lccccccc}
\hline $\begin{array}{l}\text { Hemp-lime } \\
\text { thickness: }\end{array}$ & $\begin{array}{c}\text { Total } \\
\text { thickness: } \\
\mathrm{mm}\end{array}$ & $\begin{array}{c}\text { Mass per } \\
\text { unit area: } \\
\mathrm{kg} / \mathrm{m}^{2}\end{array}$ & $\begin{array}{c}U \text {-value } \\
U: \mathrm{W} / \mathrm{m}^{2} \mathrm{~K}\end{array}$ & $\begin{array}{c}\text { Admittance } \\
\mathrm{Y}: \mathrm{W} / \mathrm{m}^{2} \mathrm{~K}\end{array}$ & $\begin{array}{c}\text { Admittance } \\
\text { Lead time } \\
\omega: \mathrm{h}\end{array}$ & $\begin{array}{c}\text { Decrement } \\
\text { factor } \\
f\end{array}$ & $\begin{array}{c}\text { Decrement } \\
\text { lag time } \\
\phi: \mathrm{h}\end{array}$ \\
\hline 50 & 683 & 914 & 0.58 & 4.59 & 1.35 & 0.02 & $19 \cdot 87$ \\
100 & 733 & 929 & 0.45 & 4.59 & 1.35 & 0.01 & $22 \cdot 33$ \\
150 & 783 & 944 & 0.37 & 4.6 & 1.35 & 0.008 & 25 \\
200 & 833 & 959 & 0.31 & 4.59 & 1.35 & 0.005 & 28.57 \\
250 & 883 & 974 & 0.27 & 4.59 & 1.35 & 0.003 & $30 \cdot 17$ \\
\hline
\end{tabular}

The surface factor 0.49 and surface lag time $1.68 \mathrm{~h}$ are constant

Table 11. Transient thermal properties of $500 \mathrm{~mm}$ dry cob walls, $20 \mathrm{~mm}$ internal lime-sand plaster, air cavity with installed hemp-lime insulation and tile hanging to shed driving rain

are exposed, but the tile hanging sheds wind-driven rain. The surface factor $F$ and the surface lag time $\psi$ have again been omitted as they remain constant with increasing hemp-lime insulation thickness at 0.46 and $1.68 \mathrm{~h}$, respectively. Table 10 shows that the wall with $250 \mathrm{~mm}$ of installed hemp-lime insulation meets the $U$-value target of $0.3 \mathrm{~W} / \mathrm{m}^{2} \mathrm{~K}$.

Care must be taken when spraying hemp-lime onto the cob at the eaves, around doors and windows to avoid jeopardising these architectural features. A possible solution would be to construct a timber frame - some sections temporary, some permanent - around these features, allowing an air cavity between the cob and the insulation. Before the addition of the hemplime, the exposed top sections of these cavities could be sealed with timber to prevent water penetration when rain water flows vertically down the wall.

Table 11 presents the thermal properties of $500 \mathrm{~mm}$ dry cob walls with $20 \mathrm{~mm}$ internal lime and sand plaster, a stud frame with plywood sheathing giving a $50 \mathrm{~mm}$ air cavity before the installed hemp-lime insulation and then tile hanging. With the air cavity in this construction, the cob is protected and the hemp-lime is exposed. The surface factor $F$ and the surface lag time $\psi$ have again been omitted as they remain constant with increasing hemp-lime insulation thickness at 0.49 and $1.68 \mathrm{~h}$, respectively. Table 11 shows that the wall with $250 \mathrm{~mm}$ of installed hemp-lime insulation meets the target $U$-value of $0.3 \mathrm{~W} / \mathrm{m}^{2} \mathrm{~K}$.

\section{Discussion}

Five concerns are now discussed: caution, sustainability, acceptability, uncertainty in data and possible savings in energy, money and carbon dioxide.

\subsection{Caution}

The wall of a building separates the internal and external climates, and the material of the wall experiences hydrothermal 
changes. By way of illustration, low-permeability sand-cement render has been implicated in $73 \%$ of cob failures (Keefe et al., 2001). It follows that the retrofitting of insulation to traditional buildings requires a careful and sympathetic approach. Traditional buildings were continuously heated, predominantly with radiative heat sources, and continuously occupied by people wearing many layers of natural material clothing. After World War II, dwellings were increasingly centrally heated by convection, fewer layers of clothing made from artificial fibres were worn and dwellings were occupied and heated intermittently. Interior design comfort temperatures rose by some $6^{\circ} \mathrm{C}$ between 1880 and 1980 (Griffiths, 2007). The burning of coal, coke or wood in fireplaces for domestic heating produced unhealthy atmospheres and was discouraged. Retrofitting insulation to a heritage building structure should therefore be undertaken with care.

\subsection{Sustainability}

Sustainability has three interwoven strands (Otto, 2003)

- social aspects, about people

- environmental aspects, about the planet

- economic aspects, about the profit.

Clearly, the upgrading of cob walls will depend strongly on people and the social aspects of the proposed modifications. The method of upgrading the thermal performance of heritage buildings will have to be socially acceptable, as well as efficient and economic.

\subsection{Acceptability}

Probert (2010) reported a study of possible tenant participation in the sustainable issues involved in Victorian property refurbishment. The tenants were very proud of their properties and expressed the preference that savings in energy should be made by installing water-saving devices, draught proofing, loft insulation and double glazing, rather than making potentially damaging changes to the external appearance of their homes. The survey suggested that people were more interested in comfort and security, in a new boiler and controls, than in increased wall insulation.

Following Probert (2010), at a Devon Earth Building Association meeting in 2010, a simple attendee questionnaire showed a similar response. A concern about external appearance was again expressed.

\subsection{Uncertainty in data}

All the tables in this paper have uncertainty. To indicate the degree of uncertainty, a number of cob samples with different hemp-lime insulation layers were studied and the wall $U$-value plotted as a function of the thickness of hemp-lime insulation. Figure 1 illustrates these studies for a $600 \mathrm{~mm}$ cob wall with

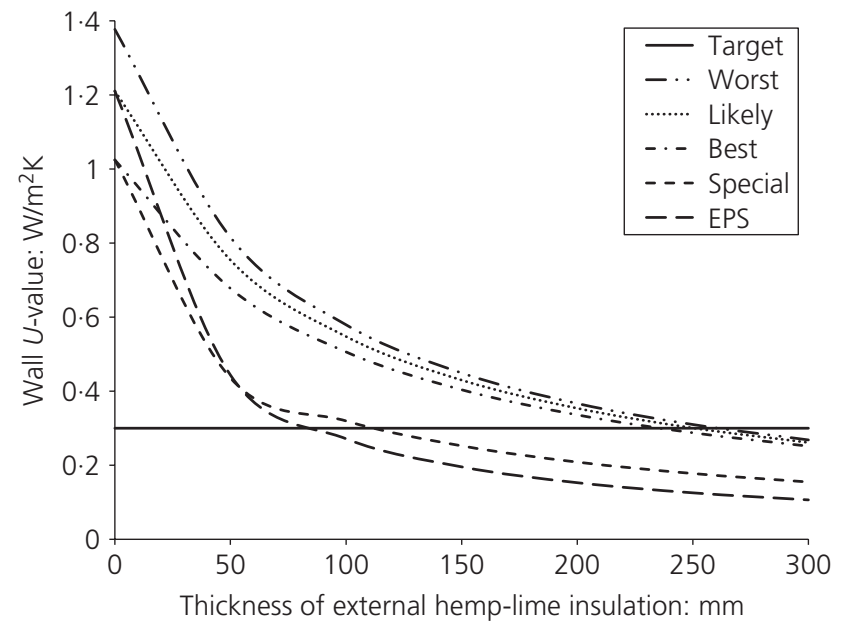

Figure 1. Variation of $U$-value $\left(\mathrm{W} / \mathrm{m}^{2} \mathrm{~K}\right)$ for a $600 \mathrm{~mm}$ cob wall for worst, likely, best and special case of cob with hemp-lime insulation, plotted against hemp-lime thickness $(\mathrm{mm})$

similar internal plaster and external render lime-sand layers. Four cases were explored. The worst case had wet cob with a thermal conductivity of $1.2 \mathrm{~W} / \mathrm{m} \mathrm{K}$ insulated with installed hemp-lime. Here, it is assumed that the hemp-lime has a conductivity of $0.1 \mathrm{~W} / \mathrm{m} \mathrm{K}$ and a density of $300 \mathrm{~kg} / \mathrm{m}^{3}$, due to self-loading. Figure 1 shows that this example requires $250 \mathrm{~mm}$ of insulation to achieve the target $U$-value of $0.3 \mathrm{~W} / \mathrm{m}^{2} \mathrm{~K}$. Second, the likely case had moist cob, conductivity of $1.0 \mathrm{~W} / \mathrm{m} \mathrm{K}$, with an installed hemp-lime. Again, $250 \mathrm{~mm}$ of hemp-lime insulation is required to meet the target. The best case had dry cob, a conductivity of $0.8 \mathrm{~W} / \mathrm{m} \mathrm{K}$ with installed hemp-lime. Again, $250 \mathrm{~mm}$ of insulation is required. Finally, the special case had dry cob with ideal hemp-lime insulation and a conductivity of $0.06 \mathrm{~W} / \mathrm{m} \mathrm{K}$. This wall has the advantage of the air cavity formed using plywood sheathing on a stud frame before the insulation. In this example, the external surface is protected by tile hanging and the target $U$-value is achieved with only $125 \mathrm{~mm}$ of hemp-lime insulation. Alternatively, if EPS (Table 1), with a thermal conductivity of $0.04 \mathrm{~W} / \mathrm{m} \mathrm{K}$, is used instead of hemp-lime insulation, then a moist cob wall requires only $100 \mathrm{~mm}$ of EPS to achieve a $U$-value of $0.3 \mathrm{~W} / \mathrm{m}^{2} \mathrm{~K}$. However, EPS is not considered a sustainable material. Paper or wool, with a thermal conductivity of 0.042 and $0.038 \mathrm{~W} / \mathrm{m} \mathrm{K}$, respectively, might provide a sustainable alternative, achieving similar insulation with layers of about $100 \mathrm{~mm}$ thickness.

A measure of the advantage of adding hemp-lime insulation was explored using the $U$-value ratio (UR). If the uninsulated $U$-value is $U_{1}$ and the insulated $U$-value is $U_{2}$, then UR is $\left(U_{1}-U_{2}\right) / U_{1}$. The values of UR for both 500 and $600 \mathrm{~mm}$ cob walls, as worst, likely and best cases described above, with two 
thicknesses of hemp-lime insulations were studied; namely $150 \mathrm{~mm}$, a practical layer and $250 \mathrm{~mm}$, a layer to meet the Building Regulations target of $0.3 \mathrm{~W} / \mathrm{m}^{2} \mathrm{~K}$. The UR values for all these combinations range from 0.64 to $0 \cdot 85$, or a mean value of $0 \cdot 75$. These values of UR are used below to discuss the possible energy and carbon dioxide savings.

\subsection{Possible savings - energy, money and carbon dioxide}

The retrofitting of external hemp-lime insulation to cob has three green/sustainable advantages

- it produces a saving in the energy required to space heat dwellings

- the sequestration of carbon dioxide by growing hemp reduces the carbon dioxide in the atmosphere

- the reduction in heating energy demand reduces the annual production of carbon dioxide.

The sequestration of carbon dioxide and its subsequent storage within the hemp-lime insulation is a single contribution to the reduction in carbon dioxide. However, the reduced energy demand provides an additional annual contribution to this reduction.

To illustrate this, three fractions are used. First, the fraction $D$ is the fuel used for space heating relative to the total fuel used, $1-D$ being the fraction used for water heating, cooking, lighting and domestic electronics. Using this fraction will overcome the problem of isolating the various energy components in the dwelling. When a dwelling uses both gas and electricity for space heating, water heating and cooking, it is difficult to distinguish the contributions made by separate fuels to the space heating. Second, assume that for the uninsulated cob walls the fraction of the total space heating lost by way of the wall fabric transmittance is $S ; 1-S$ being the fraction lost by way of the floor, ceiling, glazing, doors and ventilation. The third fraction UR was introduced in Section 6.4. As an example, consider the likely wall with $150 \mathrm{~mm}$ of installed hemp-lime insulation, the wall $U$-value decreases from 1.21 to $0.43 \mathrm{~W} / \mathrm{m}^{2} \mathrm{~K}$. The value of UR is $(1 \cdot 21-0 \cdot 43) / 1 \cdot 21$ or $0 \cdot 64$. The money saving can now be found since it is equal to the total annual fuel bill $C$ multiplied by $D$ (taken as $0 \cdot 7$ ) times $S$ (taken as $0 \cdot 35$ ) times UR $(0 \cdot 64)$, or the annual fuel bill $C$ times $0 \cdot 16$. For a total annual bill of $£ 1100$, this amounts to a saving of $£ 170$ per year.

The spread in possible energy saving can be assessed using the values from Section 6.4. Here, it was reported that the UR had a range from 0.64 to 0.85 . This would achieve a reduction in fuel bills in the range of 0.16 times $C$ to 0.21 times $C$. Again, using the total annual fuel bill of $£ 1100$, the annual saving would be from $£ 170$ to $£ 230$.
The sequestration of carbon dioxide can be summarised following Weight et al. (2010). They report that the production of lime binder produces $0.43 \mathrm{~kg}$ carbon dioxide per $\mathrm{kg}$ of lime binder, while growing hemp shiv removes $1.41 \mathrm{~kg}$ carbon dioxide per $\mathrm{kg}$ of shiv. The ideal hemp-lime mixture has $165 \mathrm{~kg}$ of binder to $110 \mathrm{~kg}$ of shiv (Section 4) and therefore an overall reduction in carbon dioxide of $0.31 \mathrm{~kg}$ carbon dioxide per $\mathrm{kg}$ of hemp-lime mixture. If a layer of hemp-lime insulation of thickness $150 \mathrm{~mm}$ is applied, then the mass of insulation per unit area is $40 \mathrm{~kg} / \mathrm{m}^{2}$. The sequestration of carbon dioxide per unit area of wall is $13 \mathrm{~kg}$ carbon dioxide per unit area. This is a significant contribution to carbon dioxide reduction, given that the total wall area of a dwelling is of the order of $80 \mathrm{~m}^{2}$.

The reduction in annual energy demand produced by the hemp-lime insulation leads to an annual reduction in the carbon dioxide produced by space heating the dwelling. A simple estimate of this reduction can be obtained by assuming the mean price of fuel to be $£ 0 \cdot 06 / \mathrm{kWh}$. Therefore, the mean saving in $\mathrm{kWh}$ is $£ 170$, from above, divided by $£ 0 \cdot 06 / \mathrm{kWh}$ or $2830 \mathrm{kWh}$ of gas per year. This $2830 \mathrm{kWh}$ of gas burning is equivalent to $520 \mathrm{~kg}$ carbon dioxide per year, since the CT (2010) suggests that $1 \mathrm{kWh}$ of gas utilised produces $0 \cdot 184 \mathrm{~kg}$ of carbon dioxide.

These calculations are intended to illustrate the possible savings and a number of assumptions have been made. The energy used in a dwelling is subjective, depending on the building design, the condition and maintenance, lifestyle and comfort conditions sought by occupants and the local climate.

\section{Conclusions}

There was excellent agreement between the reported wall thermal properties (CIBSE, 2006) and the values obtained using the bespoke Excel spreadsheets.

To conclude, the following four identified aims are addressed.

- The results highlight the need for insulation if cob dwellings are to meet the requirements of present regulations. Typical cob walls have $U$-values $>1 \mathrm{~W} / \mathrm{m}^{2} \mathrm{~K}$, or about three times the $0.3 \mathrm{~W} / \mathrm{m}^{2} \mathrm{~K}$ target.

- The transient thermal properties of a number of cob wall models with various thicknesses of hemp-lime insulation retrofitted to the exterior have been given in the tables.

- The work demonstrates how the thermal properties of cob walls might be upgraded to meet the current UK thermal Building Regulations (BR, 2010) to achieve a $U$-value equal to or less than $0.3 \mathrm{~W} / \mathrm{m}^{2} \mathrm{~K}$. The overall conclusion is that $250 \mathrm{~mm}$ of hemp-lime is required to achieve the target $U$-value. 
- The possible energy saving and carbon dioxide reduction have been explored when cob walls are insulated with $150 \mathrm{~mm}$ of external hemp-lime. A thickness of $150 \mathrm{~mm}$ is more practical (smaller building footprint) and it would have a lower capital cost than $250 \mathrm{~mm}$ of hemp-lime insulation. However, the heat loss reduction would be smaller since the $150 \mathrm{~mm}$ hemp-lime insulation only reduces the $U$-value to $0.45 \mathrm{~W} / \mathrm{m}^{2} \mathrm{~K}$, whereas the $250 \mathrm{~mm}$ layer would achieve the target value of $0.3 \mathrm{~W} / \mathrm{m}^{2} \mathrm{~K}$. The present cost of insulating with hemp-lime together with the present cost of energy suggests that the proposal is uneconomic at this time.

A further study will examine the thermal performance, capital costs and payback periods for a number of cob dwelling models of different designs retrofitted with external hemplime. Discussing the economic issues of adding hemp-lime to the exterior of cob buildings is a complex task. The area of cob wall is required and its relative heat loss assessed in relation to all the other heat loss routes from a given dwelling.

\section{REFERENCES}

Bevan R and Woolley T (2008) Hemp Lime Construction. IHS BRE Press, Bracknell, UK.

BR (Building Regulations) (2000, 2010) Conservation of Fuel and Power. Approved Document L1 Conservation of Fuel and Power in Dwellings. DTLR, NBS, RIBA Enterprises, London, UK. See http://www.safety.odem. gov.uk/bregs/brpub/ad/ad-11/index01.htm (accessed 20/10/2011).

CIBS (Chartered Institution of Building Services) (1980) Guide A3, Thermal Properties of Building Structures. CIBS, London, UK.

CIBSE (2006) Environmental Design Guide A, 7th edn. CIBSE and London and Page Bros, Norwich, UK.

CT (Carbon Trust) (2010) Resources - Conversion Factors ' $k W h$ ' into ' $\mathrm{kg}$ of Carbon Dioxide Equivalent' - Conversion Table. The Carbon Trust, London, UK. See http://www. carbontrust.co.uk/cut-carbonreduce-costs/calculate/carbonfootprinting/pages/conversion-factors.aspx\# (accessed 29/09/2010).

Goodhew S and Griffiths R (2005) Sustainable earth walls to meet the building regulations. Energy and Buildings 37: 451-459.

Griffiths R (2007) The acoustics and ventilation design tool applied retrospectively to four 19th century buildings. Building and Environment 42: 3373-3383.

Griffiths R and Goodhew S (2012) Sustainability of solid brick walls with retrofitted external hemp-lime insulation. Structural Survey 30(4): 312-332.

Hurd J and Gourley B (eds) (2000) Terra Britannica: $A$ Celebration of Earthen Structures in Great Britain and
Ireland. English Heritage/ICOMOS UK, James and James, London, UK.

Keefe L (2005) Earth Building: Methods and Materials, Repair and Conservation. Taylor \& Francis, London, UK.

Keefe $L$ and Childs P (2000) Devon and Cornwall. In Terra Britannica: A Celebration of Earth Structures in Great Britain and Ireland (Hurd J and Gourley B (eds)). English Heritage/ICOMOS UK, James and James, London, UK.

Keefe L, Watson L and Griffiths R (2001) A proposed diagnostic survey procedure for cob walls. Proceedings of the Institution of Civil Engineers - Structures and Buildings 146(1): 57-65, http://dx.doi.org/10.1680/stbu.2001.146.1.57. Otto BK (2003) About: Sustainability. Design Council, London, UK. See http://www.designcouncil.org.uk/webdav/servlet/ XRM?Page/@id=6004\&Session/@id=D_ wK2jr8zM7zumlQsB2NDz\&Section/@id=1317 (accessed $12 / 10 / 2010)$.

Pilkington B, Griffiths R, Goodhew S and de Wilde P (2008) Thermal probe technology for buildings: transition from laboratory to field measurements. Journal of Architectural Engineering 4(4): 111-118.

Pipes LA (1957) Matrix analysis of heat transfer problems. Journal of the Franklin Institute 623: 195-206.

Probert A (2010) Tenant participation in the sustainable refurbishment of Victorian properties. The Environmentalist 15(94): 17-22.

Walker P, Keable R, Martin J and Maniatidis V (2005) Rammed Earth: Design and Construction Guidelines. IHS BRE Press, Watford, UK.

Warren J (2000) Introduction. In Terra Britannica: A Celebration of Earthen Structures in Great Britain and Ireland (Hurd J and Gourley B (eds)). English Heritage/ ICOMOS UK, James and James, London, UK.

Weight D, Langdon D and Norton A (2010) Climate Change and the Role of Biomass Based Building Materials. National Non-Food Crops Centre (NNFCC), York, UK.

\section{HOW CAN YOU CONTRIBUTE?}

To discuss this paper, please email up to 500 words to the editor at journals@ice.org.uk. Your contribution will be forwarded to the author(s) for a reply and, if considered appropriate by the editorial board, it will be published as discussion in a future issue of the journal.

Proceedings journals rely entirely on contributions from the civil engineering profession (and allied disciplines). Information about how to submit your paper online is available at www.icevirtuallibrary.com/page/authors, where you will also find detailed author guidelines. 